\title{
The Use of Idioms and Wordplay in The Big Bang Theory Sitcom
}

\author{
Lendita Kryeziu \\ University of Prishtina "Hasan Prishtina", Kosovo \\ Lendita.kryeziu@uni-pr.edu
}

\begin{abstract}
Language is a powerful communication tool. A skilful person uses words and manipulates them for different purposes; be that for persuading clients into buying different products or joining a congregation; soothing aggravated patients and consoling people who lost their loved ones. Language is used for teaching, informing, entertaining and making people laugh. Many public speakers, teachers, politicians and leaders use humour for breaking the ice and engaging the audience into listening. Moreover, nowadays a vast number of sitcoms are popular among different age groups based on the topic, genre and the audience's field of interest. One such series which has caught the interest of a broader audience on Netflix is The Big Bang Theory. The usage of idioms, wordplays, puns, rhyming structures, pop culture language and scientific jargon, permeated with humour, are widely spread into the characters' daily conversations through entire episodes. From the linguistic point of view, the corpus of The Big Bang Theory episodes will be thoroughly analysed for the idioms, wordplays, puns and other structures that transmit humorous messages to the audience.
\end{abstract}

Keywords: humour, idioms, sitcom, wordplay, word formation, language

\section{Streszczenie}

Użycie idiomów i gry słów w sitcomie The Big Bang Theory (,Teoria wielkiego podrywu”)

Język jest potężnym narzędziem komunikacji. Zręczny mówca używa słów i manipuluje nimi dla osiagnięcia różnych celów: aby nakłonić klientów do zakupu pewnego typu produktów lub zachęcić ich do przylaczenia się do danej wspólnoty wyznaniowej; aby ukoić cierpienie pacjentów lub pocieszyć tych, którzy stracili swoich bliskich. Język ma za zadanie uczyć, informować, dostarczać rozrywki $i$ wywoływać śmiech. Duża grupa osób publicznych, w tym nauczyciele, politycy i przywódcy, stosuja humor, aby przełamać pierwsze lody i przykuć uwage stuchaczy. Obecnie niezwykła popularnościa wśród wielu grup wiekowych ciesza się seriale komediowe tzw. sitcomy, nawiazujace do specyficznych tematów, problemów i zainteresowań widzów. Jednym z takich seriali, który wzbudził wielkie zainteresowanie wśród użytkowników platformy Netflix, jest The Big Bang Theory (,,Teoria wielkiego podrywu”). We wszystkich odcinkach tej serii codzienne rozmowy bohaterów wypetnione sa różnego rodzaju wyrażeniami idiomatycznymi, gra słów, rymowankami, językiem pop kultury i żargonu naukowego, które 
nasycone sa humorem. Przedmiotem analizy w niniejszej pracy jest zasób leksykalny serialu „Teoria wielkiego podrywu”, gdzie idiomy, gry słowne i inne struktury językowe staja się środkami przekazania publiczności treści humorystycznych.

Słowa kluczowe: humor, idiomy, sitcom, gra słów, słowotwórstwo, język

\section{Introduction}

People have always found the ways to communicate to each other using nonverbal or verbal language. Many dictionaries describe language as a method of human communication which is either spoken or written. Language entails the use of words in a structured and conventional manner. Besides conveying different messages which can be of serious matter, language can be used for expressing humor and entertaining audience. Humor, as an important part of humankind, is manifested through language in various forms; be that through the aid of nonverbal language forms such as: mimicry, gestures or movements, or by using wordplay, puns, rhymes, alliteration, or idioms.

The importance of humor for people's lives can be explained through its usage even during the recent global pandemic explosion of COVID-19. People manage to integrate humor in their daily life. They have recreated various situations, compiled songs and parodies, written dialogues and memes associated to the current circumstances. The core focus of humor is in online learning during quarantine and eating habits due to isolation and social distancing of people. Apparently, humor serves as a balance for maintaining psychological stability in people through arduous times.

Idioms and wordplay in many cases create ambiguity which results in humorous situations. This ambiguity can be either lexical: based on a homonym or homophone that is polysemous, or syntactical where the entire structure of a clause is ambiguous. One such example is given by Attardo, in which the word "club" has an ambiguous meaning: either as an association dedicated to a particular interest or activity or as a long, thin stick used in golf to strike the ball.

Q: Do you believe in clubs for young men?

A: Only when kindness fails. (Attardo 1994: 97)

Generally, polysemous words can be ambiguous and that ambiguity leads to humorous situations. This is the reason why they are used predominantly in situational comedies as television series. From this point of view, one of the most popular TV series, The Big Bang Theory, has been treated as a corpus for analyzing language in the function of humor. 
The purpose of exploring and analyzing the language of a sitcom is based on the research question of whether idioms, wordplays, puns, and scientific jargon function as humorous devices. Moreover, the paper aims at identifying the most predominant language structures as devices that denote humor. The other objective of the paper is to investigate whether these language structures are widely spread into the characters' daily conversations through entire episodes.

The most distinctive representative cases of humor have been collected and discussed in detail while attempting to answer the underlying research questions. Fortunately, the entire corpus of The Big Bang Theory has been previously transcribed by the website: Big Bang Theory Transcripts ${ }^{1}$ which facilitated the whole process of analyzing the corpus. In this popular sitcom, Leonard Hofstadter and Sheldon Cooper are both brilliant physicists working at Cal Tech University in California. They are colleagues, best friends, and roommates. Sheldon has strict and non-conventional ways of living. They are also friends with their Cal Tech colleagues, the engineer Howard Wolowitz, and astrophysicist Rajesh Koothrappali. All of them spend their time either working on their individual work projects, or playing video games, watching sciencefiction movies, eating lunch or reading comic books. Things take a new turn when Penny, a good-looking woman, moves into the apartment across the hall from Sheldon and Leonard.

The corpus has been read and analyzed in order to detect and collect the aimed linguistic forms which function as puns and jokes through the characters' roles. Moreover, these typical examples have been elaborated within the context which is followed by their denotation and connotation.

\section{The use of homophones, homographs and abbreviations in the function of humor}

Words can be polysemous when they are homonyms or homophones while creating a humorous context based on that ambiguity. To this issue, Crystal (2006: 176) asserts that wordplay, by means of bending and violating the rules of the language, involves some non-conventional or novel manipulation of linguistic forms, and its function is merely to be enjoyed.

The following part of the research integrates idiosyncratic examples of wordplay which are included in the researched sitcom. The language forms have been selected according to the

\footnotetext{
${ }^{1}$ Source: https://bigbangtrans.wordpress.com/?pages-list. Date: 13.01.2021.
} 
division suggested by Delabastita (1996: 130). There are puns based on phonological and graphological structure, lexical structure as well as morphological, and syntactic structure.

Many examples of phonological structures like homophones and abbreviations are placed in the text with a special connotation to humor. In the following example, Sheldon being protective of his laptop uses the acronym "AFK". Penny while not comprehending the acronym requests its interpretation. When Sheldon explains the meaning, Penny confirms plainly with "Oh, I see" which Sheldon perceives as another acronym "OIC." The use of wordplay is manifested through the exclamatory formulaic structure "Oh, I see", which can also function as a homophonic acronym "OIC" (S02E03).

Furthermore, other cases of homonymic abbreviations are used intentionally for the purpose of humor which explicitly illustrate Sheldon's nerdiness and naivety. Sheldon designed the team shirts for the physics Super-bowl in Star Trek colors carrying "AA" and "PMS" acronyms as their team names. The "AA" and "PMS" acronyms according to Sheldon denote the "army ants" and "Perpetual Motion Squad". Leonard is concerned that people might misunderstand their denotation which is "Alcoholics Anonymous" and "Premenstrual Syndrome" (S01E13).

Homonyms, by having the same orthographic and phonological form and different denotations can express polysemy in relation to humor. Bert as a geologist is often undermined by Sheldon who does not consider geology as a proper science. Nevertheless, Bert invites Amy and Penny at a party where not many people appear. Trying to sound funny and popular, Bert says that he is going to turn on some "rock music", which he contemplates as amusing when used in a circle of geologists. As a response to that, Penny tries to blend in by creating another joke about geology. She uses the homophone "granted" which is articulated similarly to "granite" (S10E03).

Regarding homophones, other cases of usage can be identified in the corpus. In one of the episodes, Leonard and his friends Howard and Rajesh spend the night out. Leonard opens by revealing how he hates his name because it contains the word "nerd" in it. The word "nerd" /n3:(r)d/, in a derogatory manner refers to an unattractive, socially awkward, and boring person who is, however, intellectually capable (S03E08).

Additionally, other cases of homophones are detected in the transcripts. "Lumen" /' lu:mən/, which denotes the standard unit for measuring the brightness of light has some similarity in pronunciation with the word lemon /'lemən/. The stress falls in the first syllable, and the second syllable contains the phoneme shwa. On many occasions, Howard fails in the attempt of delivering jokes. The twisting of the citation "when life gives you lumens, make lumenade", is 
one of these attempts. Sheldon being very strict regarding grammar ironizes at his expense saying: "these two words are not quite identical" (S12E14).

Penny, a beautiful blonde waitress at the Cheesecake Factory and an inspiring actress moves into the apartment across the hall from Sheldon and Leonard. Her personality drastically contrasts with the personalities of the other male characters in the series. In one of the episodes, Leonard goes outside to invite Penny for lunch but he sees her kissing someone, so he turns back. Sheldon mocks him by using polysemy through the idiom "a penny for your thoughts" (S01E03). In the second case, Howard notices Penny and provokes her by using the homonym penny through the rhyme: "See a Penny, pick her up, and all the day you'll have good luck" (S01E07).

Words that share the same orthographic or phonologic forms can operate as perfect devices in the function of humor in language. Such is the case with the numerous abbreviations and homophones applied in the corpus and explained in the preceding paragraphs.

\section{The use of word-formation as wordplay in the function of humor}

The concept "Lexicon" denotes the word stock of a language, whereas words and phrases are referred by the term lexemes. Languages gradually get enriched with numerous novel lexemes, either through different word-formation processes or borrowings. A vast number of humorous lexemes acknowledged as neologisms are frequently encountered in various situational comedies. Standardly, these neologisms are applied crucially for naming new inventions and breakthroughs. Moreover, speakers of a language will additionally include novel words and coinages in their registers for the fundamental reason of making language more colorful and expressive. Humorous neologisms are derived through various word-formation processes.

Regarding word-formation, Huddleston and Pullum state that lexical word-formation is related to the dictionary. It describes the processes by which new lexical bases are formed. They also add that three major processes involved in lexical word-formation are compounding, derivation, and conversion (Huddleston, Pullum 2002: 28).

There are many statements that languages change continually since new words and expressions become potential lexemes and enter the lexicon. In addition to this, Huddleston and Pullum state the possibility of establishing some grammatical words as potential words: "Grammatical words like policeability which are not established will be referred to as potential words; they have the potential to become established" (Huddleston, Pullum 2002: 1624). 
Moreover, regarding this idea, Aronoff and Fudeman summarize that: "Novel words are all around us. Jerry Seinfeld has talked about the shushers, the shushees, and the unshushables in a movie theater. Morley Safer was dubbed quirkologist - expert on quirky people - on a special episode of 60 Minutes. For those who hate buffets, the TV character Frasier Crane came up with the term smorgsaphobia. Finally, the longest novel morphologically complex word we have been able to find on our own in the daily press is deinstitutionalization, from the New York Times" (Aronoff, Fudeman 2011: 5).

\subsection{Affixation in the function of creating neologisms and wordplay}

The most frequent neologisms identified in The Big Bang Theory sitcom have been derived through the processes of word-formation like affixation, blending, acronyms, and compounding. The most distinctive forms in the corpus derive from suffixation. One idiosyncratic example is compiling nouns with nominal suffixes -er and -ee. The character, Rajesh Koothrapali suffered from selective mutism. That condition prevented him from talking to women outside his family unless he was under the influence of alcohol or medication, in the first five series. Raj meets Penny outside Sheldon and Leonard's apartment and apologizes for his delay since he was caught up chatting with Penny. Perceiving this, his friends are surprised how he could speak to Penny. In this reference, the nonexistent word "chatee" has been produced. The suffix -ee creates nouns that denote a person who is the object or beneficiary of the act which is specified by that respective verb. In this manner, Raj wanted to emphasize that he listened more than he essentially talked by saying: "Actually, I was less the chatter than the chattee". In other words, he was more of a listener than a talker (S01E02).

Part of suffixation is also inflection of nouns that denote plural. Cases of pluralizing proper nouns have also been articulated for the script. Amy was discussing with Penny and Sheldon that Leonard is at the center of their friendship, and everything depends on him. Amy hyperbolizes that: if it was a town, it would be "Leonardville". If it were an Islamic nation, it would be called "Leonardstan". If it was the birthplace of motion pictures, they would refer to him as "Leonardwood". Penny, being annoyed by Amy's opinion that everything revolves around Leonard, pluralizes Leonard's name by referring to him and his circle as "Leonards". Killing two birds with one stone, Penny refers to them as a bunch of nerds (S04E01).

Foreign suffixes have equally been used for the creation of neologisms. The affix -ectomy denotes surgical removal of all or part of a particular organ. A significant number of medical terms contain this suffix. It is even used humorously on some occasions in informal speech. The 
word "parentectomy" means cutting off contact with one's parents, whereas "humorectomy" denotes a fictional operation that has removed somebody's sense of humor. Similarly, the word "Sheldonectomy" has been used in the corpus. Sheldon, known for his hypochondriac personality and characterized by strict adherence to routine and hygiene asks for numerous checkups from Stephanie regarding his health. Stephanie, annoyed by Sheldon's frequent distractions acts as if she really did something to him just to please his inquisitive nature. When Leonard asks what was going on, Stephanie replied that she performed a "Sheldonectomy". Perceiving this, Leonard retorts humorously that if you do not extract it all, it will come back even worse, like cancer (S02E10).

Additionally, other cases of affixation have been manifested in the script. Sheldon who is notorious for correcting grammar mistakes makes an intentional mistake in reference to being surprised after being thrown out of their friend's apartments. The structure is "curiouser and curiouser" (S01E12). The very same expression was used by Alice in the novel: Alice in the Wonderland by Louis Carol.

The diminutive and gender marking suffix has correspondingly been applied by Howard when greeting his friends, Sheldon, Leonard, and Penny using the phrase: "Greetings, homies, homette" (S03E09).

Many adjectives are derived from nouns by adding the suffix -ish. Sheldon known for his fixation on Standard English criticizes the use of -ish in numerals denoting time: "She's going to be home at eight-ish. Like, when is that? 8:01? 8:02?" And what kind of scientist uses -ish? Penny, being annoyed by this remark, responds: "I'll give it a go, my ride home with you was hell-ish" (S11E05).

Words as adjectives deriving from nouns by adding the suffix -y have also been presented in the corpus. Amy, while providing the reasons why Sheldon did not like the suggestions for the wedding venue used some non-existent and informal expressions: "Some were too beachy; some were to cliffy; and all of them were too outsidy" (S11E09).

Affixation as a very productive process of word-formation has been excessively used in compiling neologisms that apply to the existing rules of derivation. The representative affixes which have been used in deriving new words are mainly suffixes such as: -ee, -ette, -ectomy, ish, and $-\mathrm{y}$. 


\subsection{Blending as a word-formation process}

Nearly $40 \%$ of word-formation processes is represented by blending which is used in the corpus in the form of puns and wordplay. Many neologisms are created by blending proper and common nouns. One of such words is the blend "beefaroni" which is used informally as the name of a dish. Beefaroni consists of the word beef and macaroni. In The Big Bang Theory sitcom, most of the scenes are situated either in the dining room or in the University's cafeteria. The four friends most of the time go to the cheesecake factory, where Penny works, and order to eat or drink. Rajesh as an Indian is prohibited from consuming beef, but he loves eating it. He refers to the dish as "beefaroni" (S03E04).

In the lexical field of words associated with food, other blends have additionally been used. Since Penny and her friends spend most of the time having lunch and dinner together, their conversation is related to favorite dishes. Howard, who lives with his mother, receives his friends over for dinner on many occasions and that is the reason why he mentions some of the Jewish recipes. One of them is "tur-briska-fil" which derives from the first syllable of the noun turkey, two syllables of the noun brisket, and the preceding syllable of the Jewish word gefilte (S01E04).

In reference to words related to food, the blend brunch consists of the first segment of the word breakfast and the final part of the word lunch. Its literal meaning is a meal between breakfast and lunch. Similarly, the blend "dinfast" is found in the script. This word is blended between the first part of the word dinner and the second component of the word breakfast. As far as the context is concerned, Leonard is in a relationship with Priya who is living in India. $\mathrm{He}$ prepares to talk to her while having dinner. Sheldon interferes by correcting Leonard that it is breakfast time for Priya and he will have "dinfast" with her, not dinner (S05E02).

In the lexical field of words related to food, another neologism has been produced for the transcript. The word "Ph.D.-licious" consists of the acronym $\mathrm{PhD}$ and two last syllables of the word delicious. In the majority of blends, the last sound of the first part is also the first sound of the second word. In this case, the sound /d/ is the common sound of two words. Sheldon is very proud of his achievements and likes to boast how he possesses a brilliant mind. Sheldon displays an intense superiority complex and is immediately turned off to anyone he does not value on an intellectual level. In this context, while being congratulated on the publication of his and Amy's paper, Sheldon raises a toast and brings to attention that he is a proud holder of two Ph.D. thesis by saying: "Ooh, that is Ph.D.-licious" (S12E11). 
Besides spending time eating together, Leonard and his company devote a lot of time to playing games and screening Marvell movies. Some of the words identified in the corpus are coined from the field of comics and various games. One of them is "trestling" which is blended from the second part of the word Tetris and the second part of the word wrestling (S01E16).

Additionally, there are many blends that are coined by different words and used in the script. The majority of blends will be recorded without any accompanying context for the mere reason of economizing with text and space. Sheldon is obsessed with flags and in one of his documentaries handles the blend: "flagtacular" which comprises of the word flag and the two preceding syllables of the second word spectacular. (S08E10) Similarly, in reference to flags, the blend "flagkeeters" which is derived from the word flag and two final syllables of the word musketeers (S08E10).

Moreover, related to the lexical field of the lexeme "documentaries", other blends are articulated by Sheldon as well. Sheldon is known for his sympathy towards the Star Trek character that he identifies himself with since he feels they are intelligent, logical, and unemotional. Sheldon calls Amy on the phone even though they broke up thinking that she would like to watch him being interviewed for a broadcast about Mr. Spock. He implements the blend "Spockumentary", which consists of the first syllable of the word Spock and the preceding segment of the word documentary (S09E07). The syllable /ock/ is the common sound of the word Spock and documentary. A similar blend "Rocktober" has equally been articulated in the script by the geologist Bert. This blend is comprised of the words rock and October. The last sound /ok/ of the word rock is commonly the first sound of the word October (S11E07).

From all characters of The Big Bang Theory sitcom, Sheldon is the one that manipulates with coinages more than the others. In the range of coined forms, the word "dogapus" has been found in the source. When Leonard asks what is a dogapus, Sheldon explains that it is a dog and octopus, the man's underwater most beloved friend. The reason that Sheldon likes this dogopus is that it can play fetch with six balls (S04E02).

A vast number of new words have been derived by the process of word-formation. The most frequent ones are blends that have been coined by using proper nouns and favorite dishes as well as names of the various types of games and game characters. The fact that characters spent a lot of their free time working, playing and eating together justifies the use of neologisms (blends) related to the aforementioned lexical fields. 


\subsubsection{Blending of proper nouns}

The most frequent blends used in the script are blended words derived from proper nouns. The majority of blended nouns are referred to Sheldon and his innovativeness. Some of them are created by Sheldon since he expresses his egocentrism by identifying numerous characters adapting his name. The term "Sheldor" derives from the name Sheldon and the preceding syllable of the lexeme conqueror (S02E03).

In the group of blended expressions with proper nouns and other words, the blend "Pregnadette" has also been identified in the corpus. It is composed of two syllables of the word pregnant and the last syllable of the proper noun. Bernadette, known for being incredibly competitive, is afraid she might lose a significant research project because of her pregnancy. Because of this fear, Bernadette pleaded Penny not to report to anyone about her pregnancy. Penny might have slipped the secret by informing Leonard and, from mouth to mouth, the secret goes to Ruchi's ears. Ruchi works with Bernadette, and Penny feels intimidated by her for the research projects and her position (S11E08).

Sheldon and his friends engage in various games throughout several episodes. Throughout the games that are frequently focused on popular comics, Sheldon likes to label his characters implementing his name by adding some modifications. On one occasion, Sheldon experiences stage fright and Raj tries to encourage him to overcome his anxiety through meditation. Raj instructs Sheldon to imagine that he is in a place that he feels like at home. Sheldon says he designed "Sheldonopolis". Sheldon remains a perfectionist, thus he requires detailed instructions like in which particular place is "Sheldon Square, Sheldon Towers, Sheldon Stadium, home of the Fighting Sheldons"? Furthermore, Sheldon emphasizes that the weather is chilly, and he is going to "Shel-Mart" to buy a sweater (S03E18).

Regarding blends with proper nouns, there are two situations when Sheldon and Raj coin neologisms with the couple's names. In one of the episodes, Raj has been trying to come up with a lovely couple's nickname for him and Emily. He requests from his friends which one they like better: "Emippali or Koothrapemily"? Howard is inquisitive to know why it is surname and Emily's forename. The reason was that her surname is Sweeney, and it did not seem right about "Koothrapeeney" as a nickname. The two first blends are created with Emily's name and Raj's surname (S08E02).

Sheldon's friends are immensely surprised by the news that Sheldon started dating Amy and thus Howard comes up with the blend "Shamy". The coinage that comprises of the first 
sound of the names Sheldon and Amy resonates with the word shame and the adjectival suffix -y (S04E01).

Blends take a significant position in the group of coinages in the corpus. The majority of the blends applied in the script are derived from proper and common nouns or between two proper nouns such as "Pregnadette" and "Shamy".

\section{Rhyme in the function of humor}

Playing with language can be described as the intentional manipulation of the idiosyncrasies of a linguistic system in a way that draws attention to the peculiarities of language. These language manipulations can be described through numerous kinds of puns and form-based alterations like rhymes and alliteration.

Rhyme remains an essential tool for creating an easy verse. The humorous poems in English, or in any other language, frequently maintain a pattern of end-rhymes. Rhyme amuses the reader's perception and makes the poem understandable. In many dictionaries, rhyme is a repetition of similar-sounding words, occurring at the end of lines in poems or songs. Dictionaries describe that rhyme is a device for utilizing the repeating patterns that bring rhythm or musicality to poems which differentiates them from prose. Typically, a rhyme is engaged for the specific purpose of exposing a pleasing effect to a poem for an enjoyable and memorable experience.

According to Schröter, two words or strings of words rhyme if at least the preceding stressed vowel and all following sounds are identical. In languages where spelling and pronunciation mirror each other closely, the final letters in rhyming pairs will also tend to be identical, but in theory, spelling does not play a role in the presence or absence of rhyme. Chew, shoe, loo and glue thus rhyme with one another as much as with new, canoe, moo, and true (Schröter 2005: 293).

In The Big Bang Theory sitcom, humor is also realized through rhymes and alliteration. The majority of rhymes originate from Sheldon who is also prone to proper use of grammar and standard language. Sheldon's obsession for cleanliness causes him to break into Penny's extremely untidy apartment in the middle of the night and clean it up. Leonard goes after him trying to prevent him from getting into trouble. At one moment, Leonard leans while trying to persuade Sheldon to get back. At this sight, Sheldon uses the rhyme: "If you have time to lean, you have time to clean" (S01E02). 
For every discomfort or trouble that Sheldon experiences, he runs to his neighbor Penny and seeks her advice which would assist him in interaction with the others. There are many occasions that he uses rhyme, which annoys Penny. That is why, on his way out, Sheldon wants to seek from Penny one last thing, which she approves only if it does not rhyme. Sheldon gives up apparently because of the issue he aspired to announce rhymed. He merely replied with "Alright. Goodnight". The pun is that these two words rhyme on the sound pattern /att/ (S02E21).

Bernadette's feelings have been offended since Amy was not the first person to mock her about her squeaky voice. She found it hard to be taken seriously when she was the most petite person in the room. Sheldon reciprocates similar feelings since in high school he was smallwaisted and only nine years old. Bernadette reveals to Sheldon that in high school, students used to address her with "Bernadette the marionette" (S12E06).

Sheldon and his friends camp out to attend a screening of one of their favorite comic books. There was a massive queue ahead and one person tries to cut the line. Sheldon, who is known for respecting rules and conventions, interferes with the expression: "No cuts, no buts, no coconuts" (S04E08).

While Leonard is talking on-line with his girlfriend, Sheldon goes to Penny's apartment to provide them some privacy. Sheldon liked Penny's new chair until he finds out that it is a used chair collected from the street. Sheldon, who is so apprehensive of germs and contracting infections, does whatever he can to compel Penny to get rid of it. Penny declines all his attempts and after Sheldon's notorious knocks on the door, Penny makes fun of him by using the rhymes: "What's the word hummingbird? What's up, buttercup? What's the gist, physicist?" (S05E02).

It is a general notion that idioms are memorable because they rhyme. In one of the series, Sheldon is entering the apartment and while being angry with Leonard does not wait for him. In answering to Leonard why he did not hold the door, Sheldon says "Hold the door, get robbed some more". When Leonard replies that no one says that Sheldon states that they should since it is accurate and it rhymes (S11E18).

Not everything that rhymes can be beautiful or humorous, but in majority of cases, rhyme which is uttered through Sheldon's character adds more humor to his eccentric and nonconventional ways of living. The corpus is filled with humorous rhymes, punchlines and memorable idioms through which humor is expressed. 


\section{The use of euphemisms in humor}

The euphemisms are used to avoid unpleasant expressions in everyday communication. Fromkin and Rodman define a euphemism as "a word or phrase that replaces a taboo word or serves to avoid frightening or unpleasant subjects" (1993: 304). People habitually use euphemisms either intentionally or unintentionally as to avoid offending someone. These phrases are lexicalized and established as a norm.

Wardhaugh defined euphemisms as "words and expressions that allow us to talk about unpleasant things and 'neutralize' the unpleasantness, e.g., the subjects of death and dying, unemployment and criminality" (Wardhaugh 1986: 237).

In humor, the utilization of euphemisms is purposeful since their goal is producing humorous situations using wordplay and puns. In this context, the corpus of The Big Bang Theory is abundant with euphemisms that incorporate humor.

As in reference to the usage of euphemism for preventing an embarrassing situation for Penny's family is when they appeared at the wedding. Penny's mother, Susan, is concerned about how her family will be perceived because of her son Randall's criminal history dealing with drugs. On one occasion when Randall is inquired about his job, he leaves that opportunity for his mother to answer since he is truly straightforward. Susan replies using the euphemism that "he is between jobs", which means, he is unemployed. Randall adds the punchline: "and court appearances" (S10E01).

Identically, in relation to Randall's illegal activities, another euphemism is used. Penny describes her brother as "a chemist". The euphemism "chemist" is used for producing and cooking methamphetamine (S03E04).

In English, there are many euphemisms for going to the toilet, such as "spend a penny", I" am going to powder my nose", "a call of nature", "to the restroom", etc. Similarly, the euphemisms: "number one and number two" are used as a reference to bodily excretory functions. In the following example, Howard boasts about his invention which is Zero-Gravity Waste Disposal System in the space shuttle. Raj ridicules him by saying this is a significant achievement, for two reasons which are "Number one and number two". Sheldon, that usually has problems identifying sarcasm, irony, and metaphors, perceives this one as a euphemism (S02E22).

Sheldon and Amy devoted a lot of time to each-other before being in a real relationship because of his autistic nature. Sheldon's inability to perceive the connotations of words and phrases leads to humorous situations. During Sheldon's birthday party, Amy says she hopes to 
see him in "his birthday suit". Sheldon replies that the clothes he is wearing are his birthday suit. Amy expresses the connotative meaning of the phrase "birthday suit". The punchline of the joke is delivered when Sheldon utters the denotative meaning of the same expression (S09E17).

Sheldon's inability to comprehend the connotative meaning of expressions leads to humorous situations. On one occasion, Sheldon is preparing dinner for Amy using medieval methods like in: "A little house on the Prairie" American drama. He asks Leonard for permission to use his room for smoking some meat. Leonard wonders whether Sheldon is using any euphemisms (S09E17).

Some of the euphemisms are primarily employed as means of preventing any offence when telling them you are lying. Usually, the euphemisms used for the concept of telling lies are "spinning a yarn", "misinterpreting facts", "telling half-truths", "pulling a fast one", and the most frequent one: "stretching the truth". Penny routinely does Yoga which involves stretching of the body posture and limbs. When Penny lied about her whereabouts, Amy said: "you are stretching the truth". The notion, "stretch" has denotative and connotative meaning at the same time in this context (S12E08).

In many cases when euphemisms are used for the purpose of functioning as a humorous device, they have their connotative meaning. The humor is intensified when these euphemisms sound funny even in their denotative meaning by being ambiguous, such were the cases: "stretching the truth" and "birthday suit".

\section{Idioms and humor in The Big Bang Theory}

Cowie summarized that idioms were perceived as: phraseological units, word-combinations, and phrasal lexemes by different linguists and researchers. Moreover, they are addressed as ready-made memorized combinations in written and spoken language which manifest a wider recognition of the crucial role which they play in first and second language acquisition and adult language production (Cowie 1998: 2).

Additionally, the idiom is defined as a group of words whose meaning is different from the meanings of the individual words in the Oxford Advanced Learner's Dictionary. Similarly, Glucksberg states that: all idioms, by definition, have at least two meanings: the linguistic meaning of the words and phrases themselves, and the stipulated, idiomatic meaning. In addition to linguistic and stipulated meanings, many idiomatic expressions also make hints to the content (Glucksberg 1993: 23). 
Idioms are widely used in the corpus and very often they are manipulated to satisfy the purpose. They are no longer fixed phrases but rather they are adapted to serve the intentional goals of the speaker.

The corpus has been researched thoroughly and only proverbial and sentential forms are collected because of the limitation of space and research. The twisted idiom: "You can lead a chicken to Crisco, but you can't make your mother fry it", is used by Sheldon because he wants her mother to cook it for him. This form is the modified version of "you can lead a horse to water but you can't make him drink" (S05E06).

Cases of substituting lexical forms in proverbs have equally been identified in the script. The idiom "through the grapevine" is substituted with: "through the nerd-vine" (S05E16).

Examples of idioms conveying both denotative and connotative meaning have been located in the corpus like: "Well, you seem hot under the collar or is that the sweater?" This idiom is used since Leonard is allergic to the woolen sweater which he is wearing as a punishment by Sheldon for not returning a DVD to the store. This is the first denotative meaning, and the second connotative meaning is that he feels irritated and uneasy about that issue (S07E08).

As a humorous reference to Penny eating all the time for free at Sheldon and Leonard's place is the punchline stated by Sheldon that "the best things in life are free". (S05E20) Additionally, other idioms are used in referential meaning. As in the scavenger hunt game, the instruction "Leave no stone unturned" gives the team hints to search at the geology laboratory, under the stones for the key of the game. This idiom carries both the denotative and connotative meaning in the context (S07E05).

A humorous situation is elicited when Kripke releases helium from the tubes while Sheldon is giving an interview. His voice becomes high-pitched and there is a burst of laughter evoked in the office. After this accident, Sheldon states that "he does not want to sink to his level". Raj replies that he cannot sink with all that helium in him, he is lucky he does not float away. Once more, the punchline was expressed by the denotative meaning of the respective clause (S03E09).

Many popular proverbs have been exploited throughout the entire episodes of The Bing Bang Theory. Some of them have been used in their unmanipulated fixed form and most of them have been modified by fitting the appropriate context. Cases when connotative and denotative meaning of idioms function equally for the purpose of humor were abundant. Some of such cases are "Hot under the collar", "Leave no stone unturned" and "The best things in life are free". However, there were cases when idioms were modified for a humorous emphasis. Some representative cases are: "Hear it through the nerdvine" and You can lead a chicken to Crisco, but you cannot make your mother fry it." 


\section{Conclusion}

Humor surrounds us in our ordinary life. It is manifested through various channels like social networks, numerous websites, television, radio, newspapers, and magazines. As a consequence of pandemic COVID-19, a vast number of people were required to stay inside and work online as a form of social distancing and prevention of infection. Most of them enjoyed more free time which they spent browsing social networks, online portals, or watching television. People need humor to amuse themselves, particularly during these disturbing times when struggling with the pandemic, unemployment, as well as economic and political instability. Nowadays, there is an abundance of situational comedies on cable TV or Netflix which provide a lot of qualitative humor as a means of entertainment.

Similarly to other people, I was compelled to stay inside, work online, and devote my free time to watching Netflix. While watching The Big Bang Theory, I could not help but observe there were a lot of idioms, proverbs, wordplay, scientific discourse, and coinages used in the scenario. Moreover, these linguistic structures perform their function in expressing humor through protagonists' roles in the aforementioned sitcom.

Expediently, language structures like homonyms, polysemous forms, wordplays, coinages, and idioms are extensively spread in all episodes of The Big Bang Theory through characters' ordinary conversations. Sheldon is more productive in using coinages and scientific discourse. Additionally, he is prone to employing standard language and correcting his friends' mistakes. Neologisms that are produced refer to this characters' favorite hobbies and meals since most of the time they are either eating or playing games.

The coinages have been derived by the process of word-formation. They were primarily blends, acronyms, and affixations. As far as blending is concerned, the majority of blends have been coined by using proper nouns and favorite dishes, as well as names of the various types of games and game characters.

The prevalent language structures that function as humor devices in the given context are homonyms and coinages. Their polysemous nature results in lexical and syntactical ambiguities. This ambiguity frequently leads to a humorous context that is triggered by lexemes in the form of homophones, homographs, and abbreviations.

In general, the discourse is rich in scientific terminology since the principal themes of the series revolve around physics, engineering, neurology, microbiology and geology. Additionally, the coinages produced for the script are technical and scientific terms. These expressions are predominantly blends and expressions derived by affixation. 
Other figures of speech present in the discourse are alliteration, rhymes, proverbs, similes, and metonymies which also function as humorous tools when used in the proper context through the characters' roles.

\section{References}

Aronoff, Mark, Kirsten Fudeman (2011) What is Morphology? Chichester: Blackwell Publishing.

Attardo, Salvatore (1994) Linguistic Theories of Humor. Berlin: Gruyter.

Cowie, P. Anthony (1998) Phraseology, Theory, Analysis, and Applications. New York: Clarendon Press.

Crystal, David (2006) Words, Words, Words. New York, Oxford: Oxford University Press.

Delabastita, Dirk (1996) "Introduction." The Translator 2 (2); 127-139. https://doi.org/10.1080/13556509.1996.10798970.

Fromkin, Victoria, Robert Rodam (1993) An Introduction to Language. Harcourt Brace: Harcourt Brace College Publishers.

Glucksberg, Sam (1993) “Idiom Meanings and Allusional Content.” [In:] Cristina Cacciari, Patrizia Tabossi (eds.) Idioms: Processing, Structure, and Interpretation. Hillsdale, Hove, London: Lawrence Erlbaum Associates; 3-26.

Huddleston, Rodney, Geffrey Pullum (2002) The Cambridge Grammar of the English Language. New York: Cambridge University Press.

Schröter, Thorsten (2005) Shun the Pun, Rescue the Rhyme? - The Dubbing and Subtitling of Language-Play in Film. Karlstad: Karlstad University Studies.

Wardhaugh, Ronald (2006) An Introduction to Sociolinguistics. New York: Basil Blackwell Inc. 